\title{
Activity of Iranian Medicinal Herbs against Human Intestinal Parasites (HIP): A Systematic Review
}

\author{
Masoud Soosaraei \\ (PhD Candidate) Toxoplasmosis \\ Research Center, Mazandaran \\ University of Medical Sciences, Sari, \\ Iran and Student Research Committee, \\ Department of Parasitology, School of \\ Medicine, Mazandaran University of \\ Medical Sciences, Sari, Iran \\ Ahmad Daryani ID \\ (PhD) Toxoplasmosis Research Center, \\ Mazandaran University of Medical \\ Sciences, Sari, Iran \\ Shahabeddin Sarvi \\ (PhD) Toxoplasmosis Research Center, \\ Mazandaran University of Medical \\ Sciences, Sari, Iran \\ Mohamad Taghi Rahimi \\ (PhD) Center for Health Related Social \\ and Behavioral Sciences Research \\ Shahroud University of Medical \\ Sciences, Shahroud, Iran \\ Mahdi Fakhar \\ (PhD) Toxoplasmosis Research Center, \\ Mazandaran University of Medical \\ Sciences, Sari, Iran \\ Hajar Ziaei Hezarjaribi \\ (PhD) Department of Parasitology, \\ School of Medicine, Mazandaran \\ University of Medical Sciences, Sari, \\ Iran \\ Mehdi Sharif \\ (PhD) Toxoplasmosis Research Center, \\ Mazandaran University of Medical \\ Sciences, Sari, Iran \\ Corresponding author: Mahdi Sharif \\ Address: Department of Parasitology \\ and Mycology, School of Medicine, \\ Mazandaran University of Medical \\ Sciences, Sari, Iran \\ Tel: +981513241031 \\ Email: msharifmahdi@yahoo.com \\ Received: $2019 / 09 / 9$ \\ Revised: $2020 / 05 / 3$ \\ Accepted: 2020/05/6 \\ (c) (7) (8)
}

This work is licensed under a Creative

Commons Attribution 4.0 License.

\begin{abstract}
Background and objectives: Intestinal parasitic infections are a major public health problem worldwide, especially in developing countries. It is estimated that around 3.5 billion people are infected with intestinal parasites. Human intestinal parasites (HIP) are clinically important due to broad epidemiological distribution, reinfection and drug resistance. In the last decades, bioactive compounds from herbs were used against a wide variety of microorganisms including parasites. We aimed to perform a systematic review on studies on the effects of medicinal herbs on HIPs in Iran.
\end{abstract}

Methods: Relevant scientific publications until April, 2015 were extracted from five English databases (PubMed, Google Scholar, Ebsco, Science Direct and Scopus) and four Persian databases (Magiran, Irandoc, IranMedex and the Scientific Information Database).

Results: A total of 18 papers and two dissertations met the inclusion criteria. Overall, 22 different plant extracts were used against Giardia lamblia, Entamoeba histolytica, Cryptosporidium and Hymenolepis nana. Based on the results, the extracts could exert time- and dose-dependent inhibitory effects against the tested HIPs. Five plants types including Allium, Chenopodium botrys, Carum copticum, F. asafoetida and Artemisia annua were able to completely inhibit the tested parasites, while Thymus vulgaris and $A$. paradoxum showed the lowest inhibitory effect $(7 \%)$.

Conclusions: Given the findings, it is recommended to conduct in vivo studies on medicinal herbs with favorable in vitro effects against HIPs.

Keywords: Intestinal Parasites, Herbal Medicines, Plant Extracts, In vitro, In vivo

DOI: $10.29252 / \mathrm{mlj} .14 .5 .1$ 


\section{INTRODUCTION}

Intestinal helminths and protozoan infections are widely distributed around the world. Human intestinal parasites (HIPs) remain a major public health challenge, affecting millions of people, mainly in tropical and subtropical countries (1). Infections caused by HIPs are highly endemic in populations with poor hygiene and low socioeconomic status, favoring larval skin penetration and oral-fecal transmission (2). Main symptoms and complications of HIP infections include diarrhea, dysentery, hematuria, vomiting, loss of appetite, abdominal distension, mental disorders and allergies (3). Moreover, chronic infections caused by parasites such as Ascaris lumbricoides and hookworms can lead to malnutrition and anemia in high risk individuals, particularly children (2). Despite the remarkable scientific advances in health and medicine, parasitic infections are still one of the most common diseases worldwide. Intestinal protozoa are transmitted by the fecal-oral route (water contaminated with feces, soiled hands or ingestion of contaminated food). The most important intestinal protozoan infections are giardiasis (caused by G. lamblia), amoebiasis (caused by Entamoeba histolytica), cyclosporiasis (caused by Cyclospora cayetanensis), isosporiasis (caused by Isospora belli) and cryptosporidiosis (caused by Cryptosporidium $s p$ ). Prevention and control of these infections have been an important aspect of national health planning (5). Based on estimations, more than 3.5 billion people worldwide are infected with HIPs, of which 450 million are clinically symptomatic and the majority being children (6).

Despite the efforts made on prevention and control of HIPs, the prevalence is still considerable owing to drug resistance, reinfection and broad epidemiological distribution (8). Therefore, novel anti-parasitic drugs are urgently required to treat and control parasitic diseases. Medicinal herbs have recently attracted a lot of attention as suitable alternatives for chemical medicine due to several advantages including fewer side effects, high availability, low cost, and better biocompatibility(9). The history of herbal medicine is as old as the human civilization.
Herbal remedy is still the main preference of $75-80 \%$ of people in developing countries (10). In this paper, we conduct a systematic review of previous publications on the activity of medicinal herbs against HIPs in Iran.

\section{MATERIALS AND METHODS}

To gather data, a precise and comprehensive search was performed on all scientific publications (full texts and abstracts) and Iranian parasitology theses available from February to April 2015. The search was performed using five English databases (PubMed, Google Scholar, Ebsco, Science Direct and Scopus) and four Persian databases (Magiran, Irandoc, IranMedex and Scientific Information Database). The reference lists of obtained articles were also reviewed for additional relevant studies. The search terms used alone or combined were: "Intestinal parasite", "Plant", "Medicinal plant", "Herbal extract", "Herb", "Traditional", "Protozoa", "Helminth", "Entamoeba histolytica", "Giardia lamblia", "Cryptosporidium", "Natural or Herbal medicine". The synonyms of herbal medicine including "Herbal preparation", "Herbal medication", "Herbal product", "Herbal remedy", "Medicinal herb", and "Phytopharmaceutical" were also searched. Other relevant diseases and topics such as HIP were also reviewed and included if the appropriate outcomes were shown. The language of database search was limited to English and Persian.

All identified studies were independently evaluated for eligibility and inclusion by two different reviewers. Selected papers were studied carefully and repetitive papers were excluded. The following details were extracted from the included publications: year of publication, first author, target parasite, scientific name of the plants, part of the plants used for extraction, type of extract, concentration, exposure time, animal model and outcomes.

\section{RESULTS}

A total of 18 papers and two dissertations were retrieved from the databases. Figure 1 shows the study design process. According to the obtained publications, 22 types of plants were used against four intestinal parasites including G. lamblia, Cryptosporidium, Entamoeba histolytica and Hymenolepis nana. 
Allium, Chenopodium botrys and Ferula asafoetida were found as the most frequently used plants. Five plants including Allium, Chenopodium botrys, Carum copticum, $F$. asafoetida and Artemisia annua were able to completely inhibit the examined parasites, while Thymus vulgaris and A. paradoxum exhibited low inhibitory properties (7\%). In addition, aqueous and hydroalcholic extracts were the most commonly used type of extract.
The only medicinal herb that was evaluated both in vitro and in vivo was $A$. paradoxum. All in vivo studies had used Balb/c mice as the animal model. Tables 1 and 2 present characteristics of the herbal extracts and parasites used in the retrieved publications.

The studies concluded that Allium, Ch. botrys, C. copticum, $F$. asafoetida and A. anunua are promising source of anti-parasitic agents that could be potentially used for development of novel drugs against HIPs.

Figure 1. Flowchart describing the study design process

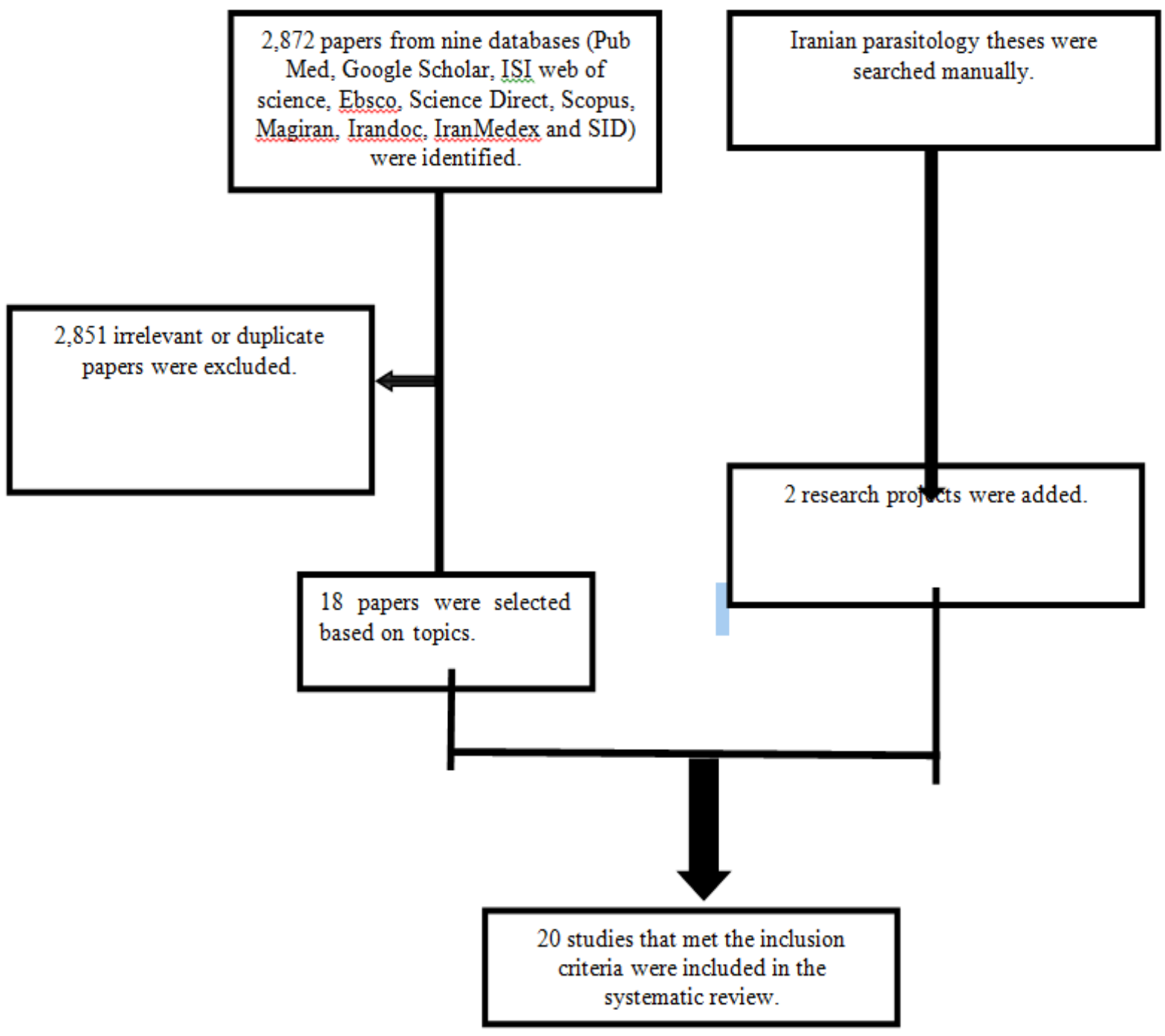


Table 1. Details of studies on the in vitro activity of

\begin{tabular}{|c|c|c|c|c|c|c|c|c|c|}
\hline No. & Parasite & Plant & $\begin{array}{l}\text { Type of } \\
\text { parasite }\end{array}$ & Extract & Part used & Concentration & Exposure time & Re: & Reference \\
\hline \multirow[b]{2}{*}{1} & $\begin{array}{c}\text { Hymenolepis } \\
\text { nana }\end{array}$ & A sativum & Cyst & - & Garlic tablets & - & - & 71.1\% effective & \multirow[t]{2}{*}{ [11] } \\
\hline & G. lamblia & A sativum & Cyst & - & Garlic tablets & - & - & $34.6 \%$ effective & \\
\hline \multirow{2}{*}{2} & G. lamblia & $\begin{array}{l}\text { Eucalyptus } \\
\text { globulus }\end{array}$ & \multirow[t]{2}{*}{ Cyst } & - & - & - & - & $\begin{array}{c}\mathrm{IC} 50=0.022 \\
\mathrm{mg} / \mathrm{ml}\end{array}$ & \multirow[t]{2}{*}[12]{} \\
\hline & E. histolytica & E. globulus & & - & - & - & - & $\begin{array}{c}\mathrm{IC} 50=3.1 \\
\mathrm{mg} / \mathrm{ml}\end{array}$ & \\
\hline 3 & G. lamblia & $\begin{array}{c}\text { Artemisia } \\
\text { annua \& } \\
\text { Thymus } \\
\text { vulgaris } \\
\end{array}$ & Cyst & Hydroalcoholic & Leaf & $\begin{array}{c}1,10,50 \text { and } \\
100 \mathrm{mg} / \mathrm{ml}\end{array}$ & 30 and $60 \mathrm{~min}$ & $\begin{array}{c}\text { Highest } \\
\text { inhibitory effect } \\
\text { at } 100 \mathrm{mg} / \mathrm{ml} \\
\text { for } 60 \mathrm{~min} \\
\end{array}$ & [13] \\
\hline \multirow[t]{6}{*}{4} & \multirow[t]{6}{*}{$\begin{array}{c}G . \\
\text { lamblia }\end{array}$} & $\begin{array}{c}\text { Allium } \\
\text { ascalonicum } 4^{\circ} \\
\text { C }\end{array}$ & Cyst & - & Bulb & & $\begin{array}{c}30 \mathrm{~min}, 1,2 \text { and } \\
3 \mathrm{~h}\end{array}$ & $\begin{array}{c}\text { The mean } \\
\text { giardiacidal } \\
\text { activity at } 4^{\circ} \mathrm{C} \\
\text { after } 3 \mathrm{~h} \text { was } \\
28.46 \%\end{array}$ & \multirow[t]{6}{*}{ [14] } \\
\hline & & $\begin{array}{c}A \text { ascalonicum } \\
24^{\circ} \mathrm{C}\end{array}$ & & - & Bulb & & $\begin{array}{c}30 \mathrm{~min}, 1,2 \text { and } \\
3 \mathrm{~h}\end{array}$ & $\begin{array}{c}\text { The mean } \\
\text { giardiacidal } \\
\text { activity at } 24^{\circ} \mathrm{C} \\
\text { after } 3 \mathrm{~h} \text { was } \\
33.86 \%\end{array}$ & \\
\hline & & $\begin{array}{c}\text { A. sativum, } \\
\mathrm{C}\end{array}$ & & - & Bulb & & $\begin{array}{c}30 \mathrm{~min}, 1,2 \text { and } \\
3 \mathrm{~h}\end{array}$ & $\begin{array}{c}\text { The mean } \\
\text { giardiacidal } \\
\text { activity at } 4^{\circ} \mathrm{C} \\
\text { after 3h was } \\
36 \%\end{array}$ & \\
\hline & & $\begin{array}{l}\text { A. sativum, } 24^{\circ} \\
\mathrm{C}\end{array}$ & & - & Bulb & & $\begin{array}{c}30 \mathrm{~min}, 1,2 \text { and } \\
3 \mathrm{~h}\end{array}$ & $\begin{array}{c}\text { The mean } \\
\text { giardiacidal } \\
\text { activity at } 24^{\circ} \mathrm{C} \\
\text { after } 3 \mathrm{~h} \text { was } \\
43 \%\end{array}$ & \\
\hline & & A cepa $4^{\circ} \mathrm{C}$ & & - & Bulb & & $\begin{array}{c}30 \mathrm{~min}, 1,2 \text { and } \\
3 \mathrm{~h}\end{array}$ & $\begin{array}{c}\text { The mean } \\
\text { giardiacidal } \\
\text { activity at } 4^{\circ} \mathrm{C} \\
\text { after } 3 \mathrm{~h} \text { was } \\
33.26 \% \\
\end{array}$ & \\
\hline & & A. сера $24^{\circ} \mathrm{C}$ & & - & Bulb & & $\begin{array}{c}30 \mathrm{~min}, 1,2 \text { and } \\
3 \mathrm{~h}\end{array}$ & $\begin{array}{c}\text { The mean } \\
\text { giardiacidal } \\
\text { activity at } 24^{\circ} \mathrm{C} \\
\text { after } 3 \mathrm{~h} \text { was } \\
41.13 \% \\
\end{array}$ & \\
\hline 5 & Amoeba cyst & $\begin{array}{l}\text { Acanthophylum } \\
\text { squarrosum }\end{array}$ & Cyst & Aqueous & Leaf & $\begin{array}{c}1,5,10,15 \text { and } \\
20 \%\end{array}$ & 0 and $15 \mathrm{~min}$ & $\begin{array}{l}\text { IC50 =7.4 mg } \\
/ \mathrm{ml}\end{array}$ & [15] \\
\hline 6 & $\begin{array}{c}G . \\
\text { lamblia }\end{array}$ & A sativum & Cyst & Chloroformic & Bulb & 4 and $8 \mathrm{mg} / \mathrm{ml}$ & $1-19 h$ & $\begin{array}{c}\text { Complete } \\
\text { elimination of } \\
\text { Giardia cyst at } \\
4 \mathrm{mg} / \mathrm{ml} \text { after } \\
13 \mathrm{hand} \text { at } 8 \\
\mathrm{mg} / \mathrm{ml} \mathrm{after} 8 \mathrm{~h} \\
\end{array}$ & [16] \\
\hline \multirow{6}{*}{7} & \multirow{6}{*}{$\begin{array}{c}G . \\
\text { lamblia }\end{array}$} & $\begin{array}{l}\text { Lemon juice } \\
4^{\circ} \mathrm{C}\end{array}$ & & Aqueous & - & - & $\begin{array}{c}30 \mathrm{~min}, 1,2 \text { and } \\
3 \mathrm{~h}\end{array}$ & $\begin{array}{c}\text { The mean } \\
\text { inhibition rate } \\
\text { was } 18.9 \% \text { after } \\
180 \mathrm{~min} \\
\end{array}$ & \multirow{6}{*}[17]{} \\
\hline & & Vinifer $4^{\circ} \mathrm{C}$ & Cyst & Aqueous & - & - & $\begin{array}{c}30 \mathrm{~min}, 1,2 \text { and } \\
3 \mathrm{~h}\end{array}$ & $\begin{array}{l}\text { The mean } \\
\text { inhabitation } \\
\text { rate was } 12.8 \% \\
\text { after } 180 \mathrm{~min}\end{array}$ & \\
\hline & & Vineger $4^{\circ} \mathrm{C}$ & & Aqueous & - & - & $\begin{array}{c}30 \mathrm{~min}, 1,2 \text { and } \\
3 \mathrm{~h}\end{array}$ & $\begin{array}{c}\text { The mean } \\
\text { inhibition rate } \\
\text { was } 28.4 \% \text { after } \\
180 \text { min } \\
\end{array}$ & \\
\hline & & $\begin{array}{l}\text { Lemon Juice } \\
24^{\circ} \mathrm{C}\end{array}$ & & Aqueous & - & - & $\begin{array}{c}30 \mathrm{~min}, 1,2 \text { and } \\
3 \mathrm{~h}\end{array}$ & $\begin{array}{c}\text { The mean } \\
\text { inhibition rate } \\
\text { was } 28.35 \% \\
\text { after } 180 \mathrm{~min} \\
\end{array}$ & \\
\hline & & Vinifer $24^{\circ} \mathrm{C}$ & & Aqueous & - & - & $\begin{array}{c}30 \mathrm{~min}, 1,2 \text { and } \\
3 \mathrm{~h}\end{array}$ & $\begin{array}{c}\text { The mean } \\
\text { inhibition rate } \\
\text { was } 16.22 \% \\
\text { after } 180 \mathrm{~min} \\
\end{array}$ & \\
\hline & & Vineger $24^{\circ} \mathrm{C}$ & & Aqueous & - & - & $\begin{array}{c}30 \mathrm{~min}, 1,2 \text { and } \\
3 \mathrm{~h}\end{array}$ & $\begin{array}{c}\text { The mean } \\
\text { inhibition rate } \\
\text { was } 40.63 \% \\
\text { after } 180 \mathrm{~min}\end{array}$ & \\
\hline
\end{tabular}




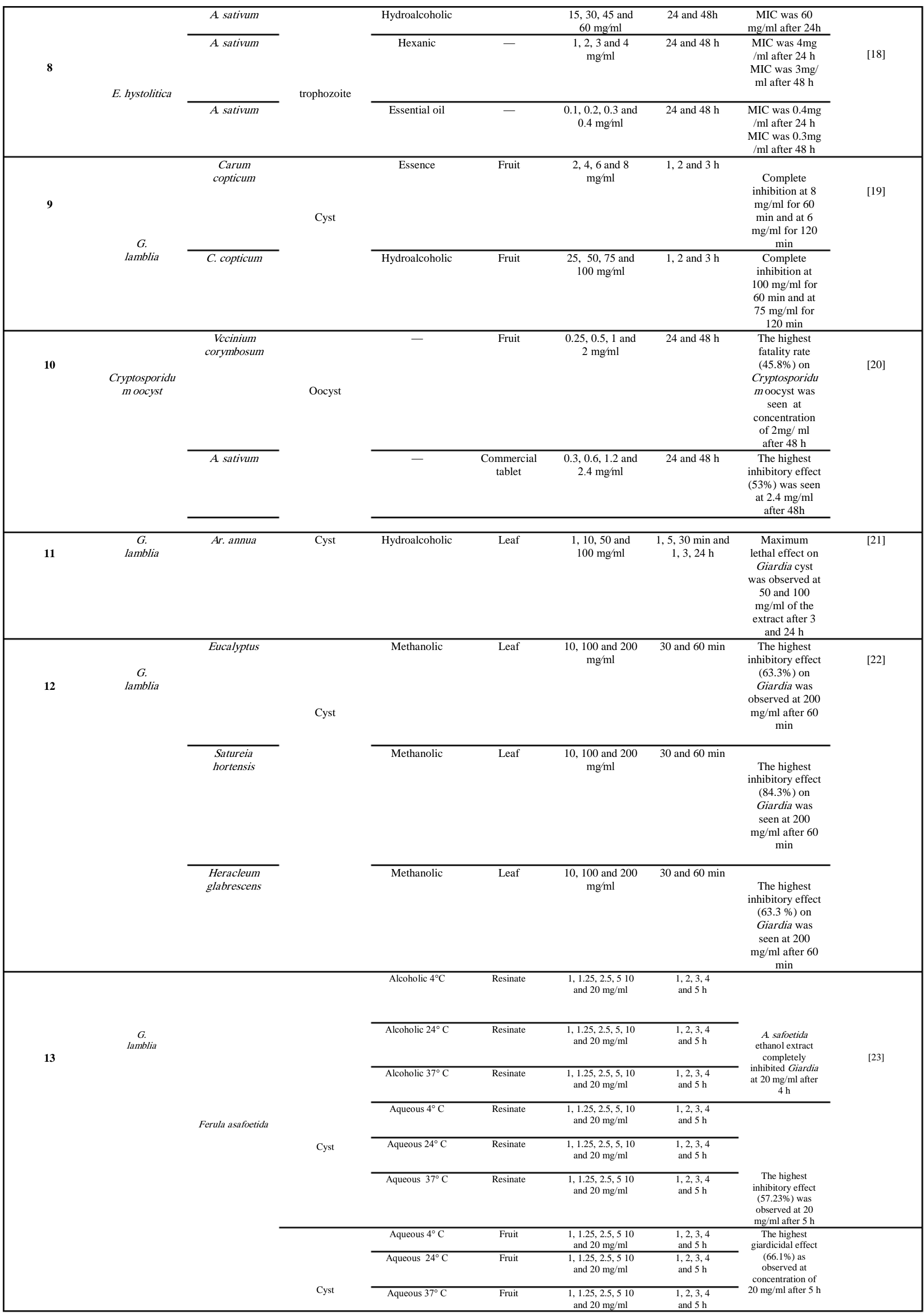




\begin{tabular}{|c|c|c|c|c|c|c|c|c|c|}
\hline 14 & $\begin{array}{c}G . \\
\text { lamblia }\end{array}$ & $\begin{array}{l}\text { Sambucus } \\
\text { ebulus }\end{array}$ & & Methanolic & Fruit & $\begin{array}{c}1,10,50 \text { and } \\
100 \mathrm{mg} / \mathrm{ml}\end{array}$ & $\begin{array}{c}5,10,30 \\
\text { and } 60 \mathrm{~min}\end{array}$ & $\begin{array}{c}\text { The highest } \\
\text { inhibitory effect } \\
\text { against Giardia } \\
\text { (78\%) was } \\
\text { observed at } 100 \\
\text { mg/ml after } 60 \\
\text { min } \\
\end{array}$ & [24] \\
\hline \multirow{6}{*}{15} & \multirow{6}{*}{$\underset{\text { lamblia }}{G .}$} & \multirow{6}{*}{ Ch. botrys } & \multirow{3}{*}{ Cyst } & Alcoholic $4^{\circ} \mathrm{C}$ & Fruit & $\begin{array}{c}1,1.25,2.5,5 \\
10 \text { and } 20 \\
\mathrm{mg} / \mathrm{ml}\end{array}$ & $\begin{array}{l}1,2,3,4 \\
\text { and } 5 \mathrm{~h}\end{array}$ & \multirow{3}{*}{$\begin{array}{c}\text { Complete } \\
\text { elimination of } \\
\text { Giardia at } 37 \\
{ }^{\circ} \mathrm{C} \text {, with } 20 \\
\mathrm{mg} / \mathrm{ml} \text { after } 5 \mathrm{~h}\end{array}$} & \multirow{6}{*}{ [25] } \\
\hline & & & & $\begin{array}{c}\text { Alcoholic } 24^{\circ} \\
\text { C }\end{array}$ & Fruit & $\begin{array}{c}1,1.25,2.5,5 \\
10 \text { and } 20 \\
\mathrm{mg} / \mathrm{ml}\end{array}$ & $\begin{array}{l}1,2,3,4 \\
\text { and } 5 \mathrm{~h}\end{array}$ & & \\
\hline & & & & $\begin{array}{c}\text { Alcoholic } 37^{\circ} \\
\text { C }\end{array}$ & Fruit & $\begin{array}{c}1,1.25,2.5,5 \\
10 \text { and } 20 \\
\mathrm{mg} / \mathrm{ml}\end{array}$ & $\begin{array}{l}1,2,3,4 \\
\text { and } 5 \mathrm{~h}\end{array}$ & & \\
\hline & & & \multirow{3}{*}{ Cyst } & Aqueous $4^{\circ} \mathrm{C}$ & Fruit & $\begin{array}{c}1,1.25,2.5,5 \\
10 \text { and } 20 \\
\mathrm{mg} / \mathrm{ml}\end{array}$ & $\begin{array}{l}1,2,3,4 \\
\text { and } 5 \mathrm{~h}\end{array}$ & \multirow{3}{*}{$\begin{array}{l}\text { The highest } \\
\text { giardicidal } \\
\text { effect }(66.1 \%) \\
\text { as observed at } \\
\text { concentration } \\
\text { of } 20 \mathrm{mg} / \mathrm{ml} \\
\text { after } 5 \mathrm{~h}\end{array}$} & \\
\hline & & & & Aqueous $24^{\circ} \mathrm{C}$ & Fruit & $\begin{array}{c}1,1.25,2.5,5 \\
10 \text { and } 20 \\
\mathrm{mg} / \mathrm{ml}\end{array}$ & $\begin{array}{l}1,2,3,4 \\
\text { and } 5 \mathrm{~h}\end{array}$ & & \\
\hline & & & & Aqueous $37^{\circ} \mathrm{C}$ & Fruit & $\begin{array}{c}1,1.25,2.5,5 \\
10 \text { and } 20 \\
\mathrm{mg} / \mathrm{ml}\end{array}$ & $\begin{array}{l}1,2,3,4 \\
\text { and } 5 \mathrm{~h}\end{array}$ & & \\
\hline \multirow[t]{4}{*}{16} & $\begin{array}{c}G . \\
\text { Lamblia cyst }\end{array}$ & $A r$. annua & \multirow{4}{*}{ Cyst } & Chloroformic & - & $\begin{array}{c}1,1.25,2.5,5 \\
10 \text { and } 20 \\
\mathrm{mg} / \mathrm{ml}\end{array}$ & $\begin{array}{l}5,10,30,60 \\
\text { and } 180 \mathrm{~min}\end{array}$ & $\begin{array}{c}\text { The highest } \\
\text { inhibitory effect } \\
(86 \%) \text { was } \\
\text { observed at } \\
\text { concentration } \\
\text { of } 100 \mathrm{mg} / \mathrm{ml} \\
\text { after } 60 \mathrm{~min}\end{array}$ & \multirow[t]{4}{*}{26} \\
\hline & $\begin{array}{c}G . \\
\text { lambliatroph }\end{array}$ & $A r$. аппиа & & Chloroformic & - & $\begin{array}{c}1,1.25,2.5,5 \\
10 \text { and } 20 \\
\mathrm{mg} / \mathrm{ml}\end{array}$ & $\begin{array}{l}5,10,30,60 \\
\text { and } 180 \mathrm{~min}\end{array}$ & $\begin{array}{c}\text { Complete } \\
\text { inhibition at } \\
100 \mathrm{mg} / \mathrm{ml} \text { after } \\
60 \mathrm{~min}\end{array}$ & \\
\hline & $\begin{array}{c}G . \\
\text { lamblia Cyst }\end{array}$ & $\begin{array}{c}\text { Tanacetum } \\
\text { parthenium }\end{array}$ & & Chloroformic & - & $\begin{array}{c}1,10,50 \text { and } \\
100 \mathrm{mg} / \mathrm{ml}\end{array}$ & $\begin{array}{l}5,10,30,60 \\
\text { and } 180 \mathrm{~min}\end{array}$ & $\begin{array}{c}\text { The highest } \\
\text { inhibitory effect } \\
(87 \%) \text { was } \\
\text { observed at } \\
\text { concentration } \\
\text { of } 100 \mathrm{mg} / \mathrm{ml} \\
\text { after } 60 \mathrm{~min}\end{array}$ & \\
\hline & $\begin{array}{c}G . \\
\text { lamblia troph }\end{array}$ & T. parthenium & & Chloroformic & - & $\begin{array}{c}1,10,50 \text { and } \\
100 \mathrm{mg} / \mathrm{ml}\end{array}$ & $\begin{array}{l}5,10,30,60 \\
\text { and } 180 \mathrm{~min}\end{array}$ & $\begin{array}{c}\text { Complete } \\
\text { inhibition at } \\
\text { concentration } \\
\text { of } 100 \mathrm{mg} / \mathrm{ml} \\
\text { after } 60 \mathrm{~min}\end{array}$ & \\
\hline \multirow[t]{2}{*}{17} & \multirow[t]{2}{*}{$\underset{\text { lamblia }}{G .}$} & A paradoxum & & Hydroalcoholic & Leaf & $\begin{array}{c}5,10,50 \text { and } \\
100 \mathrm{mg} / \mathrm{ml}\end{array}$ & $\begin{array}{c}1,5,10,30 \\
\text { and } 60,180 \mathrm{~min}\end{array}$ & $\begin{array}{c}\text { Complete } \\
\text { inhibition at } \\
\text { concentration } \\
\text { of } 100 \mathrm{mg} / \mathrm{ml} \\
\text { after } 180 \mathrm{~min}\end{array}$ & \multirow[t]{2}{*}{ [27] } \\
\hline & & A. paradoxum & Cyst & Chloroformic & Leaf & $\begin{array}{c}5,10,50 \text { and } \\
100 \mathrm{mg} / \mathrm{ml}\end{array}$ & $\begin{array}{c}1,5,10,30 \\
\text { and } 60,180 \mathrm{~min}\end{array}$ & $\begin{array}{c}\text { Complete } \\
\text { inhibition at } \\
\text { concentration } \\
\text { of } 100 \mathrm{mg} / \mathrm{ml} \\
\text { after } 180 \mathrm{~min}\end{array}$ & \\
\hline \multirow{6}{*}{18} & \multirow{6}{*}{$\begin{array}{c}G . \\
\text { lamblia }\end{array}$} & \multirow[t]{2}{*}{ Olea europaea } & \multirow{6}{*}{ Cyst } & $\begin{array}{c}\text { Hydroalcoholic } \\
37^{\circ} \mathrm{C}\end{array}$ & Leaf & 2 and $5 \mathrm{mg} / \mathrm{ml}$ & 2 and $4 \mathrm{~h}$ & \multirow{2}{*}{$\begin{array}{c}\text { The highest } \\
\text { inhibitory effect } \\
\text { (45.34\%) was } \\
\text { observed at } \\
\text { concentration } \\
\text { of } 2 \mathrm{mg} / \mathrm{ml} \\
\text { after } 4 \mathrm{~h}\end{array}$} & \multirow{6}{*}{ [28] } \\
\hline & & & & $\begin{array}{l}\text { Hydroalcoholic } \\
\quad 4^{\circ} \mathrm{C}\end{array}$ & Leaf & 2 and $5 \mathrm{mg} / \mathrm{ml}$ & 2 and $4 \mathrm{~h}$ & & \\
\hline & & \multirow[t]{2}{*}{ S. khuzestanica } & & $\begin{array}{c}\text { Hydroalcoholic } \\
37^{\circ} \mathrm{C}\end{array}$ & Leaf & 2 and $5 \mathrm{mg} / \mathrm{ml}$ & 2 and $4 \mathrm{~h}$ & \multirow[b]{2}{*}{$\begin{array}{c}\text { The highest } \\
\text { inhibitory effect } \\
\text { was observed at } \\
5 \mathrm{mg} / \mathrm{ml}, 4^{\circ} \mathrm{C}, \\
\text { after } 4 \mathrm{~h} \\
\end{array}$} & \\
\hline & & & & $\begin{array}{l}\text { Hydroalcoholic } \\
4^{\circ} \mathrm{C}\end{array}$ & Leaf & 2 and $5 \mathrm{mg} / \mathrm{ml}$ & 2 and $4 \mathrm{~h}$ & & \\
\hline & & \multirow[t]{2}{*}{ A sativum } & & $\begin{array}{l}\text { Hydroalcoholic } \\
37^{\circ} \mathrm{C}\end{array}$ & Leaf & 2 and $5 \mathrm{mg} / \mathrm{ml}$ & 2 and $4 \mathrm{~h}$ & \multirow{2}{*}{$\begin{array}{c}\text { The highest } \\
\text { inhibitory effect } \\
(36.69 \%) \text { was } \\
\text { observed at } \\
\text { concentration } \\
\text { of } 5 \mathrm{mg} / \mathrm{ml} \\
\text { after } 4 \mathrm{~h} \text { at } 37 \\
{ }^{\circ} \mathrm{C}\end{array}$} & \\
\hline & & & & $\begin{array}{l}\text { Hydroalcoholic } \\
4^{\circ} \mathrm{C}\end{array}$ & Leaf & 2 and $5 \mathrm{mg} / \mathrm{ml}$ & 2 and $4 \mathrm{~h}$ & & \\
\hline
\end{tabular}


Table 2. Details of studies on the in vivo activity of medicinal herbs against HIPs in Iran.

\begin{tabular}{|c|c|c|c|c|c|c|c|c|c|c|}
\hline $\begin{array}{l}\mathbf{N} \\
\mathbf{o}\end{array}$ & Parasite & Plant & Kind of parasite & Extract & Part used & Concentration & $\begin{array}{r}\text { Exposu } \\
\text { re time } \\
\text { (days) }\end{array}$ & $\begin{array}{c}\text { Animal } \\
\text { model }\end{array}$ & Results & Ref. \\
\hline \multirow{3}{*}{1} & $\begin{array}{c}G . \\
\text { lamblia }\end{array}$ & $\begin{array}{c}A \\
\text { paradoxum }\end{array}$ & \multirow{3}{*}{ Cyst } & Hydroalcoholic & Leaf & $\begin{array}{c}20,50 \text { and } 100 \\
\mathrm{mg} / \mathrm{ml}\end{array}$ & 3 & $\mathrm{Balb} / \mathrm{c}$ & $\begin{array}{c}\text { The highest inhibitory } \\
\text { effect }(7 \%) \text { was observed at } \\
\text { concentration of } 100 \mathrm{mg} / \mathrm{ml} \text { after } 3 \\
\text { days }\end{array}$ & \multirow{3}{*}{ [29] } \\
\hline & $\begin{array}{c}G . \\
\text { lamblia }\end{array}$ & $\begin{array}{c}A \\
\text { paradoxum }\end{array}$ & & Hydroalcoholic & $\begin{array}{l}\text { Leaf and } \\
\text { bulb }\end{array}$ & $\begin{array}{c}20,50 \text { and } 100 \mathrm{mg} \\
/ \mathrm{ml}\end{array}$ & 3 & $\mathrm{Balb} / \mathrm{c}$ & $\begin{array}{c}\text { The highest inhibitory } \\
\text { effect }(71 \%) \text { was observed at } \\
\text { concentration of } 100 \mathrm{mg} / \mathrm{ml} \text { after } 3 \\
\text { days }\end{array}$ & \\
\hline & G. lamblia & $\begin{array}{c}A \\
\text { paradoxum }\end{array}$ & & Hydroalcoholic & Bulb & $\begin{array}{c}20,50 \text { and } 100 \mathrm{mg} \\
/ \mathrm{ml}\end{array}$ & 3 & Balb/c & $\begin{array}{c}\text { The highest inhibitory } \\
\text { effect }(66 \%) \text { was observed at } \\
\text { concentration of } 100 \mathrm{mg} / \mathrm{ml} \text { after } 3 \\
\text { days }\end{array}$ & \\
\hline 2 & $\begin{array}{c}G . \\
\text { lamblia }\end{array}$ & $\begin{array}{l}\text { Tanacetum } \\
\text { parthenium }\end{array}$ & Cyst & Chloroformic & Bulb & $\begin{array}{c}20,50 \text { and } 100 \\
\mathrm{mg} / \mathrm{ml}\end{array}$ & 3 & Balb/c & $\begin{array}{c}\text { Treatment with } 100 \mathrm{mg} / \mathrm{ml} \\
\text { for } 3 \text { days treated } 90 \% \text { of infected } \\
\text { mice }\end{array}$ & [30] \\
\hline
\end{tabular}

\section{DISCUSSION}

The present systematic review is the first to present valuable data about the efficacy of plant extracts against HIPs in Iran during 1998-2015.

The majority of investigations were conducted on $G$. lamblia, which may be due to the fact that this parasite is the main causative agent for persistent parasitic diarrhea throughout the word. This flagellate parasite is also the most common (14.7\%) pathogenic protozoan in Iran (31).

Climate is an important variable of parasitic infections. Iran is located in West Asia and borders the Persian Gulf, Caspian Sea and Gulf of Oman. The country has a variable climate, but in the northwestern areas, winters are cold with subfreezing temperatures and heavy snowfall during December and January. Spring and fall are relatively mild, while summers are dry and hot. In the south, winters are mild and the summers are very hot, having daily average temperatures exceeding $38{ }^{\circ} \mathrm{C}$ $\left(100.4^{\circ} \mathrm{F}\right)$ in July. In most parts of the country, annual precipitation averages $250 \mathrm{~mm}(9.8$ inch) or less. The north usually has a humid climate with temperatures seldom below freezing in winter (33). Considering all the above mentioned facts, Iran has a favorable condition for the activity of intestinal parasites.
Allium: Allium species grow in temperate climates of the northern hemisphere. This perennial plant belongs to the Liliaceae family. It has been known to possess medicinal and dietary properties (39).

The anti-helminthic (40, 41), anti-protozoal (42, 43), antibacterial (44), anti-tumor (45), antioxidant (46) and anti-fungal (47) activities of A. sativum (garlic) have been welldemonstrated.

According to the reviewed publications, most studies have been carried out on the effects of Allium against HIPs. A. sativum has long been used by humans due to its numerous health benefits. This complex herb contains an unusually high concentration of sulfurcontaining compounds (1-3\%), 17 amino acids, enzymes and minerals such as selenium. The sulfur-containing compounds are responsible for garlic's strong odor and many of its medicinal effects.

Allicin (diallyl thiosulfinate or diallyl disulfide) is the most biologically active ingredient of garlic. Kaempferol and quercetin also have inhibitory effects against microorganisms including parasites, especially Giardia (48). 
In a study by Ankri and Mirelman, a low concentation $(5 \mu \mathrm{g} / \mathrm{mL})$ of allicin inhibited virulence of $90 \%$ of E. histolytica trophozoites (49). Based on the results of previous studies, the extract of A. sativum could be considered as a proper candidate for protozoal treatment and inhibition of G. lamblia and E. histolytica. Studies have also investigated the anti-mycotic properties of A. sativum against clinically important dermatophytes, Candida albicans and Aspergillus niger (50).

Artemisia: Artemisia is a large, diverse genus of herbs with more than 200 species belonging to the daisy family (Asteraceae). Most species of Artemisia contain secondary metabolites such as sesquiterpenes, monoterpenes, especially sesquiterpene lactones that could be responsible for the biological activities of Artemisia species. Artemisia has long been used in traditional medicine, particularly Chinese medicine. Artemisinin (a semisynthetic derivative of Artemisia) is thought to be responsible for the anti-malaria activity of Artemisia against Plasmodium vivax and $P$. falciparum (51). Furthermore, the anti-malaria activity of Artemisia has been demonstrated in primate models (52). Recent studies indicate that Artemisia can become cytotoxic in the presence of iron influx and ferrous iron, which are abundant in cancer cells. Some studies have reported the efficacy of artemisinin against various cancers $(53,54)$. Santonin, the active component of A. nilagirica, has been shown to have anti-parasitic effects against Trichinella spiralis larvae. Artemisia is effective against a wide range of pathogenic protozoan including Pneumocystis carini (56) and causative agents of cryptosporidiosis, amoebiasis, schistosomiasis, giardiasis and leishmaniasis (57). According to Ridley and Hudson (1998), the anti-parasitic activity of artemisinin relies on alkylation and oxidation of membrane proteins and lipids as well as inactivation of protein channels through generation of highly reactive oxygen-based free radicals or electrophilic intermediates (58). A study in 2012 reported that $100 \mathrm{mg} / \mathrm{ml}$ of A. апnиa extract can inhibit $97 \%$ and $100 \%$ of giardia cysts and trophozoites, respectively (21).
Ferula asafetida: Asafoetida is the oleogumresin exuded from the roots and stems of several Ferula species. This plant is widely distributed in the Mediterranean region and Central Asia and is native to the deserts of Iran. Asafoetida has been used as an antimicrobial agent in traditional medicine (59). The plant contains calcium, phosphorus, iron, carotene, riboflavin, niacin, resinous materials composed of ferulic acid, umbel-lifer one, asaresinotannols, farnesiferols A, B and $\mathrm{C}$, and about $25 \%$ gum composed of glucose, galactose, 1-arabinose, rhamnose, and glucuronic acid and volatile oil (3-17\%) consisting of disulfides as its major components, notably 2-butyl propenyl disulfide (E- and Z-isomers) and monoterpenes ( $\alpha$ - and $\beta$-pinene, etc.). Extract of this plant was effective against Trichomonas vaginalis, Leishmania major (in vitro) and Schistosoma mansoni (in vivo) (60, 61). El Deeb et al. reported phytomedicine asafoetida as a suitable natural remedy for Blastocystis sp. infection (62). In a study by Rezaiemanesh and Shirbazou, exposure to 20 $\mathrm{mg} / \mathrm{ml}$ of $f$. asafetida ethanol extract at $37{ }^{\circ} \mathrm{C}$ for four hours had $100 \%$ giardicidal effect (23).

Chenopodium botrys: This plant is native to the Mediterranean region and is an important member of the Chenopodiaceae family, which is important for phytochemical medicinal evaluation. Phytochemically chenopods contain minerals, primary metabolites, aromatic cytokinins, amino acids, hormones, carbohydrates, proteins and secondary metabolites such as lignans, catechins, flavonols, organic acids, coumarines, carotenoid terpenoides, isoflavones, phenol derivatives, sterols, saponins, sesquiterpenoids, triterpenes, glycosides, monoterpenes, vitamins, amides, amines and alkaloids. A study reported that the essential oil from $C$. botrys has significant activity against gram positive and gram negative bacteria. Besides, oil of Chenopodium fruits and flowers has anti-helmintic properties against hookworms, roundworms and tapeworms (63). Boiled and infusion of the roots, leaves and inflorescences of this medicinal plant are used for elimination of intestinal worms. 
The decoction of this plant containing up to $300 \mathrm{mg}$ dry plant material per $\mathrm{kg}$ body weight is reported to be effective for treatment of ascariasis (64).

Carum copticum (Ajwain): C. copticum is an annual herb from the family Apiaceae that has been widely used in traditional medicine. It contains terpinene, o-cymene, terpinolene, nerolidol, etc. Moreover, thymoland and carvacrol are two major components of this plant. Previous studies have demonstrated the anti-parasitic, anti-fungal, antioxidant, antibacterial and hypolipidemic effects of $C$. copticum (65). The C. copticum extract had in vitro macrofilaricidal properties against adult bovine filarial worm $S$. digitata. Furthermore, C. copticum increased infertility and mortality rate of human filarial worm Brugia malayi in vivo (66). Another study reported the inhibitory effects of $C$. copticum essential oil against protoscoleces of hydatid cyst (67). Moreover, ethyl acetate extract of $C$. copticum $(25 \mu \mathrm{g} / \mathrm{mL})$ showed in vitro antimalarial and anti-leishmanial activity (68). Hydroalcoholic extract of $C$. copticum showed leishmaniacidal activity with IC50 of $15.625 \mathrm{M}$ which was less than the IC50 of a macrophage cell line $(43.76 \mathrm{M})(69)$.

Shahabi et al. showed that the hydroalcoholic extract and essence of $C$. copticum had inhibitory effects on G. lamblia cysts (70). In another study, C. copticum powder showed more significant dose-dependent anti-parasitic and anti-helmintic effects compared to levamisole (an immunomodulator drug and anti-helminthic agent) on sheep infected with mixed nematodes (71). Extracts of $C$. copticum can eliminate nematodes owing to its high carvacrol and thymol content $(72,73)$. The extract of this plant also exerted favorable

\section{REFERENCES}

1. Handzel T, Karanja DM, Addiss DG, Hightower AW, Rosen DH, Colley DG. Geographic distribution of schistosomiasis and soil-transmitted helminths in Western Kenya: implications for anthelminthic mass treatment. American JTrop Med Hyg. 2003; 69(3): 31823.

2. Sayyari A, Imanzadeh F, Bagheri Yazdi S, Karami H, Yaghoobi M. Prevalence of intestinal parasitic infections in the Islamic Republic of Iran. East Mediterr Health J. 2005; 11(3): 377-83.

3. Garcia LS. Diagnostic medical parasitology. $5^{\text {th }}$ ed. ASM Press. 2007.

4. World Health O. Cancer pain relief: with a guide to opioid availability. $2^{\text {nd }}$ ed. WHO. 1996. effects against Eimeria tenella, the causative agent for coccidiosis in chicken (74).

Limitations and drawbacks: Most studies have evaluated the efficacy of medicinal plants against Giardia, and little attention has been paid to other HIPs. Some major factors have been neglected including concentration, exposure time and part of the herb used for extraction. In addition, only one study has been carried out to evaluate the in vivo effects of medicinal plants against HIPs. This could be due to lack of suitable laboratory animals for HIPs, while mice and hamsters are suitable for other parasites, such as Toxoplasma and Leishmania.

In addition, monitoring infected animals with intestinal parasites is relatively difficult. Furthermore, conducting preclinical investigations is more costly compared to in vitro investigations. Last but not least, none of the reviewed studies was conducted on active components of the extracts.

\section{CONCLUSION}

To our knowledge, this study is the first systematic review on the efficacy of medicinal herbs against intestinal parasites in Iran. Given the findings, it is recommended to conduct in vivo studies on medicinal herbs with favorable in vitro effects on HIPs.

\section{ACKNOWLEDGMENTS}

We would like to thank of the Vice Chancellors for Research of Mazandaran University of Medical Sciences for the financial support (Grant number: 1427).

\section{CONFLICT OF INTEREST}

The authors declare that there is no conflict of interest regarding publication of this study.

5. Francis E, Cox G, Julius $P$, Wakelin KD. Parasitology. $2^{\text {nd }}$ ed. WB Saunder. 1999; 5: 18-30.

6. Okyay P, Ertug S, Gultekin B, Onen O, Beser E. Intestinal parasites prevalence and related factors in school children, a western city sample-Turkey. BMC pub health. 2004; 4(1): 64-8.

7. Montresor A, Crompton DWT, Hall A, Bundy DAP, Savioli L. Guidelines for the evaluation of soiltransmitted helminthiasis and schistosomiasis at community level. WHO. 1998: 1-49.

8. Pink R, Hudson A, Mouriès MA, Bendig M. Opportunities and challenges in antiparasitic drug discovery. Nat Rev Drug Discov. 2005; 4(9): 727-40. 
9. Müller J, Hemphill A, Müller N. Treatment of Giardiasis and Drug Resistance. vitro Springer. 2011; 10(4): 10-21.

10. Gautam RK, Dixit PK, Mittal S. Herbal Sources of Antidepressant Potential: A Review. Int J Pharm Sci Rev Res. 2013; 18 (1): 86-91.

11. Shabani M. Effect of the Garlic drug on Giardia disease and effect of praziquantle on Himnolepis nana in Neka city. Pharmacy thesis in Tehran Univ Med Sci. 1998.

12. Saiedi A. Evaluation of some essences from medicinal plants on Giardia lamblia and Entamoeba histolytica cysts as in vitro. Pharmacy thesis. Shiraz Uni Med Sci. 1999.

13. Bahri Najafi R, Motazedian $M$, Azadbakht $M$, Sodagar R. Effect of essential oils from some medicinal plants on Giardia lamblia cyst in comparison with metronidazol. Esfehan Uni Res J. 2003; 17(2): 199-206.

14. Azadbakht M, Sajadi S, Rostami J. Giardiacidal Activity Of The Express Obtained From Bulbs Of Three Allium Species On Giardia Intestinalis Cysts. Iran J Basic Med Sci. 2003; 3(6): 184-188.

15. Azadbakht M, Yousefi Z, Shaaban KB, Ziaee H, Mehralian A. Evaluation Of Chubak Aqueous Extract In Parasite Decontamination On Vegetables And Comparison With Commercial Detergent In Sari. J Med Pla. 2005; 3(9): 51-58.

16. Safar Harandi MM, Ghaffarifar F. In vitro and in vivo effects of garlic (Allium sativum) extract on Giardia lamblia and Giardia muris. Hakim Res J. 2006; 3(9): 5864.

17. Sadjjadi SM, Rostami J, Azadbakht M. Giardiacidal activity of lemon juice, vinifer and vinegar on Giardia intestinalis cysts. Southeast Asian $\mathrm{j}$ trop med pub health. 2006; 37(3): 24-27.

18. Behnia M, Haghighi A, Komeilizadeh H, Tabaei SJS, Abadi A. In vitro antiamoebic activity of Iranian Allium sativum in comparison with metronidazole against Entamoeba histolytica. Iranian J Parasitol. 2008; 3(4): 32-8.

19. Shahabi S, Ayazi Roozbehani F, Kamalinejad M, Abadi A. Anti-giardia activity of Carum copticum on Giardia lamblia cysts in vitro. Pejouhesh. 2008; 32(4): 303-307.

20. Mehrabi M, Sadraei J, Ghafarifar F. The effects of garlic on the oocyst of cryptosporidium parvum in HANK medium. J Kordestan Uni Med Sci. 2011; 17(2): 53-60.

21. Rahimi-Esboei B, Gholami S, Azadbakht M, Ziaei H. Effect of Hydroalcholic extract of Artemisia annua on cysts of Giardia lamblia in vitro. J Mazand Uni Med Sci. 2012; 22(90): 72-80.

22. Safarnejad Tameshkel F, Khatami Nejad M, Nasrollahi A, Rahdari P, Gholam Hossein Poor F, Rahnavard A. The antimicrobial effect of methanol extracts of Eucalyptus, Satureia Hortensis and Heracleum Glabrescens on Giardia Cysts. Med Lab J. 2012; 6(2): 21-27.

23. Rezaiemanesh M, Shirbazou S. In-vitro giardicidal effect of aqueous and alcoholic extracts of Asafoetida on Giardia lamblia cyst. J Birjand Uni Med Sci. 2012; 19(1): 22-23.

24. Rahimi-Esboei B, Ebrahimzadeh M, Gholami S, Falah-Omrani V. Anti-giardial activity of Sambucus ebulus. Eur Rev Med Pharmacol Sci. 2013; 17(15): 2047-50.

25. Rezaeemanesh M, Shirbazoo S, Pouryaghoub N. InVitro Giardicidal Effects of Aqueous and Alcoholic Extracts of Chenopodium Botrys L. on Giardia Lamblia Cysts. J Torbat Heydariyeh Uni Med Sci. 2013; 1(1): 2131.

26. Gholami S, Azadbakht $M$, Ziaei Hezarjaribi $\mathrm{H}$, Rahimi-Esboei B. Anti-Giardial Activity of Chloroformic Extract of Tanacetum parthenium and Artemisia annua in vitro. Res Molecul Med. 2014; 2(1): 45-50.

27. Rahimi-Esboei B, Ghorbani A, Gholami S, Azadbakht M, Ziaei H, Taghavi M. Antiparasitic effects of Allium paradoxum as a conventional consumed vegetable. African Jo Microbiol Res. 2014; 8(31): 297983.

28. Fallahi S, Rostami A, Delfan B, Pournia Y, Rashidipour M. Effect of olive leaf, Satureja khuzestanica, and Allium sativum extracts on Giardia lamblia cysts compared with metronidazole in vitro. J Parasit Dis J. 2015; 8(1): 1-6.

29. Elmi T, Gholami SH, Azadbakht M, Rahimi-Esboei $\mathrm{B}$, Geraili Z. The effects of hydroalcoholic extract of leaves and onion of Allium paradoxum on Giardia lamblia in mice. J Shahrekord Uni Med Sci. 2014; 16(1): 13-22.

30. Elmi T, Gholami S, Azadbakht M, Ziaei H, Sari I. Effect of Chloroformic Extract of Tanacetum parthenium in the treatment of Giardia lamblia infection in Balb/c Mice. J Mazandaran Uni Med Sci. 2014; 24(1): 157-165.

31. Abasian L, Bazyar A, Shirbazo S, Sayehmiri K, Ahmad N. Prevalence of Giardia lamblia in Iran: a systematic review and Meta analysis study. Pejouhesh. 2013; 36(5): 111-6.

32. Wright JM, Dunn LA, Upcroft P, Upcroft JA. Efficacy of antigiardial drugs. Exp opin drug Saf. 2003; 2(6): 529-41.

33. Modarres R, Silva VDPR. Rainfall trends in arid and semi-arid regions of Iran. JArid Enviro. 2007; 70(2): 344-55.

34. Shahabi S. Epidemiologic study of intestinal parasites among elementary school children in ShahrYar. Research Med. 2001; 24: 133-9.

35. Firoozabadi A, Azizi M. Prevalence of intestinal parasitic infections among fast-food restaurant workers in Yazd. J Shahid Sadoghi Uni med Sci. 2003; 1(11): 2933.

36. Albonjco M, Stoltzfus R, Savioli L, Tielsch J, Chwaya H, Ercole E. Epidemiological evidence for a differential effect of hookworm species, Ancylostoma duodenale or Necator americanus, on iron status of children. Int J Epidemiol. 1998; 27(3): 530-7.

37. Mahyar A, Daneshi kohan M, Saghafi H, Rezaie M. Intestinal parasitic infections among disabled children in Qazvin. J Qazvin Uni med Sci. 2000; 4(2): 64-70.

38. Arbabi M, Talari S. Intestinal parasites prevalence in students of Kashan university of medical sciences. J Ilam Uni Med Sci. 2004; 12(3): 44-5.

39. Eja ME, Asikong BE, Abriba C, Arikpo GE, Anwan $\mathrm{EE}$, Enyi-Idoh KH. A comparative assessment of the antimicrobial effects of garlic (Allium sativum) and antibiotics on diarrheagenic organisms. Southeast Asian 
J Trop Med Pub Health. 2007; 38(2): 343-8.

40. Abdel-Salam AM, Ammar N, Abdel-Hamid AZ. Effectiveness of probiotic Labneh supplemented with garlic or onion oil against Schistosoma mansoni in infected mice. Int J Dairy Sci. 2008; 3(2): 97-104.

41. Moazeni M, Nazer A. In vitro effectiveness of garlic (Allium sativum) extract on scolices of hydatid cyst. World J Surg. 2010; 34(11): 2677-81.

42. Soffar SA, Mokhtar GM. Evaluation of the antiparasitic effect of aqueous garlic (Allium sativum) extract in hymenolepiasis nana and giardiasis. J Egypt Soc Parasitol. 1991; 21(2): 497-502.

43. Harris JC, Plummer S, Turner MP, Lloyd D. The microaerophilic flagellate Giardia intestinalis: Allium sativum (garlic) is an effective antigiardial. Microbiol. 2000; 146(12): 3119-27.

44. Martin KW, Ernst E. Herbal medicines for treatment of bacterial infections: a review of controlled clinical trials. J Antimicrob Chemother. 2003; 51(2): 241-6.

45. Milner JA. Garlic: its anticarcinogenic and antitumorigenic properties. Nutr Rev. 1996; 54(11): 826.

46. Meng Y, Lu D, Guo N, Zhang L, Zhou G. Studies On the Anti-HCMV effect of garlic components. Virol Sin. 1993; 8(2): 147-50.

47. Cai Y. Anticryptococcal and antiviral properties of garlic. Cardiol Pract. 1991; 9: 11.

48. Lawson L, Wang Z. Pre-hepatic fate of the organosulfur compounds derived from garlic (Allium sativum). Planta Med. 1993; 59(7); 688-9.

49. Ankri S, Mirelman D. Antimicrobial properties of allicin from garlic. Microb infect. 1999; 1(2): 125-9.

50. Appleton JA, Tansey MR. Inhibition of growth of zoopathogenic fungi by garlic extract. Mycolog. 1975: 67(4): 882-5.

51. Bilia AR, Lazari D, Messori L, Taglioli V, Temperini $\mathrm{C}$, Vincieri FF. Simple and rapid physico-chemical methods to examine action of antimalarial drugs with hemin: its application to Artemisia annua constituents. Life Sci. 2002; 70(7): 769-78.

52. Fidock DA, Rosenthal PJ, Croft SL, Brun R, Nwaka S. Antimalarial drug discovery: efficacy models for compound screening. Nature Rev Drug Discov. 2004; 3(6): 509-520.

53. Rowen RJ. Artemisinin: from malaria to cancer treatment. Townsend Letter for Doctors and Patient. 2002: 233(12): 86-9.

54. Lai H, Sasaki T, Singh NP, Messay A. Effects of artemisinin-tagged holotransferrin on cancer cells. Life Sci. 2005; 76(11): 1267-79.

55. Saddi M, Sanna A, Cottiglia F, Chisu L, Casu L, Bonsignore L. Antiherpes virus activity of Artemisia arborescens essential oil and inhibition of lateral diffusion in Vero cells. Ann Clin Microbiol Antimicrob. 2007; 6(1): 10-17.

56. Chen YT, Ma L, Mei Q, Tang Y, Liao XG. An experimental trial of artemether in treatment of Pneumocystis carinii in immunosuppressed rats. Chinese med J. 1994; 107(9): 673-677.

57. Dharmananda S. QING-HAO and the Artemisias Used in Chinese Medicine. 2002: 33. http://www.itmonline.org/arts/chinghao.htm.
58. Ridley RG, Hudson N. Oxidative stress and antimalarial drugs. Curr Biol. 1998; 8: 346-9.

59. Ramadan NI, Abdel-Aaty HE, Abdel-Hameed DM, El Deeb HK, Samir NA, Mansy SS. Effect of Ferula assafoetida on experimental murine Schistosoma mansoni infection. J Egypt Soc Parasitol. 2004; 34(3): 1077-94.

60. Ramadan NI, Al Khadrawy FM. The in vitro effect of Assafoetida on Trichomonas vaginalis. J Egypt Soc Parasitol. 2003; 33(2): 615-30.

61. Iranshahy M, Iranshahi M. Traditional uses, phytochemistry and pharmacology of asafoetida (Ferula assa-foetida oleo-gum-resin) A review. $\mathrm{J}$ Ethnopharmacol. 2011; 134(1): 1-10.

62. El Deeb HK, Al Khadrawy FM, El-Hameid AKA. Inhibitory effect of Ferula asafoetida L.(Umbelliferae) on Blastocystis sp. subtype 3 growth in vitro. Parasitol Res. 2012; 111(3): 1213-21.

63. Gadano A, Gurni A, Nigro López M, López P, Gratti A, van Baren C. Cytogenetic effects of aqueous extracts of the medicinal plant Paico (Chenopodium multifidum L.). Pharm Biol. 2000; 38(1): 7-12.

64. Kliks MM. Studies on the traditional herbal anthelmintic Chenopodium ambrosioides L.: Ethnopharmacological evaluation and clinical field trials. Soc Sci Med. 1985; 21(8): 879-86.

65. Boskabady MH, Alitaneh S, Alavinezhad A. Carum copticum L.: A herbal medicine with various pharmacological effects. Biomed Res Int. 2014; 2014: 111.

66. Mathew N, Misra-Bhattacharya S, Perumal V, Muthuswamy K. Antifilarial lead molecules isolated from Trachyspermum ammi. Molecules. 2008; 13( 9): 2156-2168.

67. Moazeni M, Saharkhiz MJ, Hosseini AA. In vitro lethal effect of ajowan (Trachyspermum ammi L.) essential oil on hydatid cyst protoscoleces. Vet Parasitol. 2012; 187(1): 203-8

68. Kamaraj C, Kaushik NK, Rahuman AA, Mohanakrishnan D, Bagavan A, Elango G. Antimalarial activities of medicinal plants traditionally used in the villages of Dharmapuri regions of South India. J Ethnopharmacol. 2012; 141(3): 796-802.

69. Manjili HK, Jafari H, Ramazani A, Davoudi N. Antileishmanial and toxicity activities of some selected Iranian medicinal plants. Parasitol Res. 2012; 111(5): 2115-21.

70. Shahabi S, Ayazi Roozbehani F, Kamalinejad M, Abadi A. Anti-giardia activity of Carum copticum on Giardia lamblia cysts in vitro. Pejouhesh. 2008; 32(4): 303-7.

71. Ribero D, Nuzzo G, Amisano M, Tomatis M, Guglielmi A, Giulini SM. Comparison of the prognostic accuracy of the sixth and seventh editions of the TNM classification for intrahepatic cholangiocarcinoma. HPB. 2011; 13(3): 198-205.

72. Park I-K, Kim J, Lee S-G, Shin S-C. Nematicidal activity of plant essential oils and components from ajowan (Trachyspermum ammi), allspice (Pimenta dioica) and litsea (Litsea cubeba) essential oils against pine wood nematode (Bursaphelenchus xylophilus). J nematol. 2007; 39(3): 275. 
73. Wright DJ. Nematicides: mode of action and new approaches to chemical control. Plant parasit nematod. 1981; 3: 421-449.
74. Zaman MA, Iqbal Z, Abbas RZ, Khan MN. Anticoccidial activity of herbal complex in broiler chickens challenged with Eimeria tenella. Parasitol. 2012; 139(02): 237-243.

\section{How to Cite:}

Soosaraei M,. Daryani A,. Sarvi SH,. Rahimi MT,. Fakhar M,. Ziaei Hezarjaribi H,. Sharif M. [Activity of Iranian Medicinal Herbs against Human Intestinal Parasites (HIP): A Systematic Review]. mljgoums. 2020; 14(5): 1-12. DOI: 10.29252/mlj.14.5.1 